\title{
WHAT RETIRED ENGINEER ROGER MUDGE THINKS UPON HIS SON PATRICK'S ANNOUNCEMENT OF HIS ENGAGEMENT
}

He thinks of himself at that age. He is in the courtyard of a building on the island of Rhodes, spying on a girl he saw earlier and followed home. The famous light is rinsed in blue. His shirt embarrasses him. Somewhere the turtledoves coo in soft desperation. The girl is plucking blouses from the laundry line, folding them into neat squares. He can see her feet in loose sandals, her glowing calves. He spoke to her on the plaza. She sighed her sigh of figs. Her tongue appeared for a moment and sent him tumbling. Now he stands in the long angled shadows and stares. The breeze smells of roasted fat. There is a monster inside of him, a shackled brute. In a minute she will slip inside. On the pebbles, in the rinsed blue light. She said her name. Can he live this way? She said her name. She lies on the warm stone of a nearby ruin. The fabric falls away; there is no fabric. Her body in the fatted air, her mouth beneath a red scarf. Soon she will disappear. Her bare feet will disappear. His central failure is not one of hope but obedience. When he takes a chance, it is the wrong chance. He will (for instance) depart by ship the next day, sneaking aboard without a ticket and awaken, stunned, to the shriek of Dutch gulls. He sees her skirt floating up lazily with the breeze. He has never felt this way before. He looks up. The balcony stands empty. The tops of the trees fall silent. He knows what he should not. The turtledoves are dying. The turtledoves are dead. 